\title{
Apoptotic and mitotic indices in malignant melanoma and basal cell carcinoma
}

\author{
E E Mooney, J M Ruis Peris, A O’Neill, E C Sweeney
}

\begin{abstract}
Aims-To assess the relative frequency of mitotic and apoptotic cells in malignant melanoma and basal cell carcinoma. Methods-Retrospective evaluation of haematoxylin and eosin stained slides from 10 basal cell carcinomas, 10 nodular melanomas, and 10 superficial spreading melanomas, with counting of apoptotic and mitotic cells per 1000 cells. Selected cases were studied with in situ end-labelling.

Results-The ratio of apoptotic to mitotic cells was higher in basal cell carcinoma than in either form of melanoma because of the presence of a greater number of apoptotic cells in basal cell carcinoma. Conclusion-The differing growth rates and biological behaviour of these two tumours is reflected in the apoptotic:mitotic ratio. Further assessment of this ratio is warranted, both between tumour types and between individual tumours of one type, to determine its value as an indicator of biological potential.

( $f$ Clin Pathol 1995;48:242-244)
\end{abstract}

Keywords: Apoptosis, mitosis, melanoma, basal cell carcinoma.
Department of Histopathology, St James's Hospital, Trinity College, Dublin, Ireland E E Mooney J M Ruis Peris A O'Neill

E C Sweeney

Correspondence to: Professor E C Sweeney, Department of Histopathology, St James's Street, Dublin 8 James's Streland.

Accepted for publication 25 August 1994
Amongst common malignant tumours of the skin, basal cell carcinoma and malignant melanoma show a marked difference in growth rate, despite the fact that the mitotic rate in both tumours is of near or equal value. As the rate of tumour growth depends primarily on the growth fraction of the cell population and the degree of imbalance between cell production and loss, ${ }^{1}$ it is possible that the indolent growth of basal cell carcinoma might be due to greater cell loss than that in malignant melanoma. To test this hypothesis we measured the mitotic and apoptotic rates of 10 basal cell carcinomas and compared them with the values obtained
Table 1 Characteristics of the malignant melanomas studied

\begin{tabular}{|c|c|c|c|c|}
\hline \multirow[b]{2}{*}{ Case No. } & \multicolumn{2}{|l|}{ SSMM } & \multicolumn{2}{|l|}{$N M M$} \\
\hline & Thickness (mm) & Clark's level & Thickness (mm) & Clark's level \\
\hline $\begin{array}{r}1 \\
2 \\
3 \\
4 \\
5 \\
6 \\
7 \\
8 \\
9 \\
10\end{array}$ & $\begin{array}{l}0.72 \\
1.30 \\
0.40 \\
1.20 \\
0.65 \\
0.55 \\
5.70 \\
1.80 \\
3.90 \\
0.55\end{array}$ & $\begin{array}{l}2 \\
3 \\
2 \\
3 \\
2 \\
2 \\
5 \\
4 \\
4 \\
2\end{array}$ & $\begin{array}{l}2 \cdot 10 \\
3 \cdot 50 \\
4 \cdot 20 \\
2 \cdot 00 \\
3 \cdot 40 \\
3 \cdot 10 \\
5 \cdot 00 \\
3 \cdot 70 \\
3 \cdot 00 \\
6 \cdot 00\end{array}$ & $\begin{array}{l}4 \\
3 \\
3 \\
3 \\
4 \\
4 \\
4 \\
5 \\
4 \\
5\end{array}$ \\
\hline
\end{tabular}

SSMM = superficial spreading malignant melanoma; NMM = nodular malignant melanoma in 10 superficial spreading and 10 nodular malignant melanomas.

\section{Methods}

Ten cases each of basal cell carcinoma, superficial spreading malignant melanoma and nodular malignant melanoma were randomly selected from archive material. All neoplasms were primary tumours of the skin. Standard $4 \mu \mathrm{m}$ thick haemotoxylin and eosin stained sections were reviewed. Using a grid, 1000 cells were counted in each superficial spreading malignant melanoma. In each basal cell carcinoma and nodular malignant melanoma 1000 cells were counted in both superficial and deep areas of the tumour, and an average taken. The number of apoptotic and mitotic cells per 1000 cells was calculated. Only unequivocal mitoses were counted and only viable areas of the tumour were chosen for assessment. Changes that could clearly be identified as those of apoptosis were (a) cells showing marked shrinkage of nucleus and cytoplasm or (b) fragments of cytoplasm containing dense chromatin fragments. ${ }^{2}$ Selected cases were studied using in situ end-labelling which identifies characteristic internucleosomal double stranded DNA breaks (Oncor kit, Alpha Laboratories, Eastleigh, Hampshire, UK). Sections of testis, containing meiosis induced double stranded DNA breaks, were used as positive controls. ${ }^{34}$ Bare fragments of chromatin, usually less than $3 \mu \mathrm{m}$, or amorphous fragments of debris, which could not confidently be judged to be apoptotic cells, were not counted. Other features noted were the presence or absence of ulceration, Breslow tumour thickness, ${ }^{5}$ and Clarke's level. ${ }^{6}$ Lymphocytic infiltration of tumour was assessed and graded from 0 (absent) to 3 (dense). Results were analysed using the Wilcoxon rank sum test.

\section{Results}

The Clarke's level and Breslow thickness of the malignant melanomas are shown in table 1 . Each category of malignant melanoma shows a range of lesions, with the average thickness and level of invasion of the nodular malignant melanomas being greater than in the superficial spreading malignant melanomas. The numbers of apoptotic and mitotic cells per 1000 cells (that is, the apoptotic and mitotic rates) are shown for each of the three tumour types in table 2. The number of mitoses did not exceed five per 1000 in any of the tumours studied. By contrast, the number of apoptotic cells varied considerably, with basal cell carcinoma (fig 1) 
Table 2 Apoptotic (A) and mitotic (M) figures per 1000 cells in basal cell carcinomas (BCC), superficial spreading malignant melanomas (SSMM) and nodular malignant melanomas (NMM)

\begin{tabular}{|c|c|c|c|c|c|c|c|c|c|}
\hline \multirow[b]{2}{*}{ Case No. } & \multicolumn{3}{|c|}{$B C C$} & \multicolumn{3}{|c|}{$S S M M$} & \multicolumn{3}{|c|}{$N M M$} \\
\hline & $M$ & $A$ & $\begin{array}{l}\text { Apoptosis: } \\
\text { mitosis ratio }\end{array}$ & $M$ & $A$ & $\begin{array}{l}\text { Apoptosis: } \\
\text { mitosis ratio }\end{array}$ & $M$ & $A$ & $\begin{array}{l}\text { Apoptosis: } \\
\text { motosis ratio }\end{array}$ \\
\hline 1 & 3.0 & $20 \cdot 0$ & $6 \cdot 7$ & 0 & 2.0 & ND & $2 \cdot 0$ & $2 \cdot 0$ & 1.0 \\
\hline 2 & 3.5 & 13.0 & $3 \cdot 7$ & 1.0 & 0 & 0 & 1.5 & 2.0 & $1 \cdot 3$ \\
\hline 3 & 5.0 & 16.0 & $3 \cdot 2$ & 2.0 & 1.0 & 0.5 & 5.0 & 3.5 & 0.7 \\
\hline 4 & $1 \cdot 0$ & 43.5 & 43.5 & $1 \cdot 0$ & 8.0 & 8.0 & 2.0 & 3.0 & 1.5 \\
\hline 5 & 0.5 & 5.5 & $11 \cdot 0$ & 0 & 0 & 0 & 1.0 & 7.0 & 7.0 \\
\hline 6 & 0.5 & $9 \cdot 0$ & 18.0 & $2 \cdot 0$ & $2 \cdot 0$ & 1.0 & 4.0 & 8.0 & $2 \cdot 0$ \\
\hline 7 & 0 & 24.5 & ND & 1.0 & 4.0 & $4 \cdot 0$ & 2.5 & 3.0 & $1 \cdot 2$ \\
\hline 8 & 0.5 & 5.0 & 10.0 & 0 & 1.0 & ND & 2.5 & 1.5 & 0.6 \\
\hline 9 & 1.5 & $12 \cdot 0$ & 8.0 & 3.0 & 5.0 & 1.7 & 2.5 & 5.5 & $2 \cdot 2$ \\
\hline 10 & 1.5 & 15.5 & $10 \cdot 3$ & 0 & 4.0 & ND & 4.5 & $2 \cdot 0$ & 0.4 \\
\hline
\end{tabular}

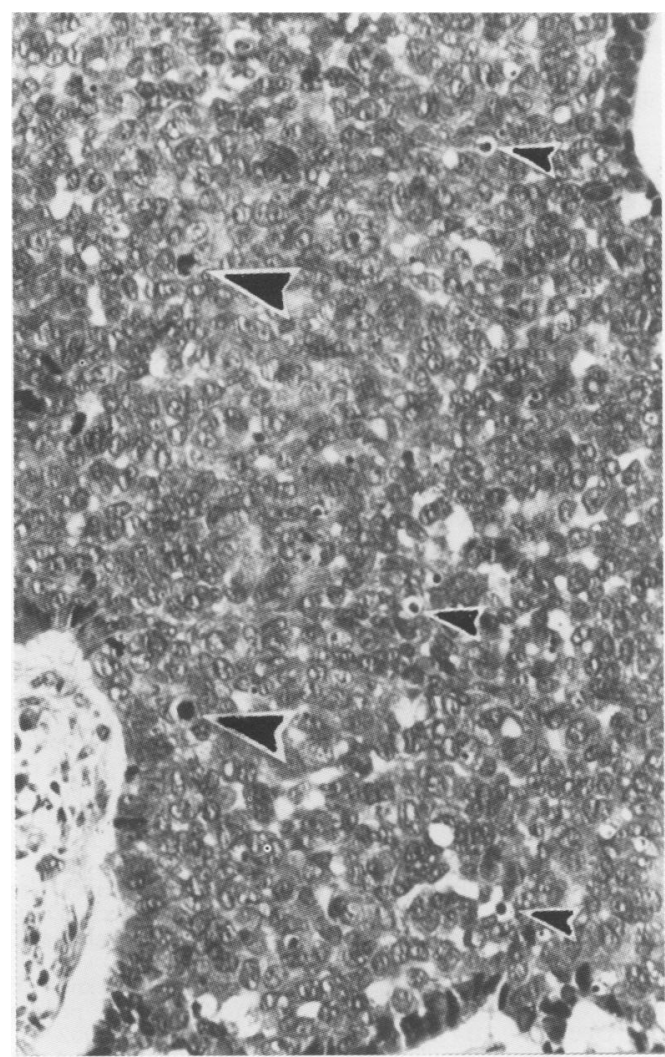

Figure 1 Basal cell carcinoma showing numerous mitotic figures (large arrowheads) and apoptotic figures (small arrowheads).

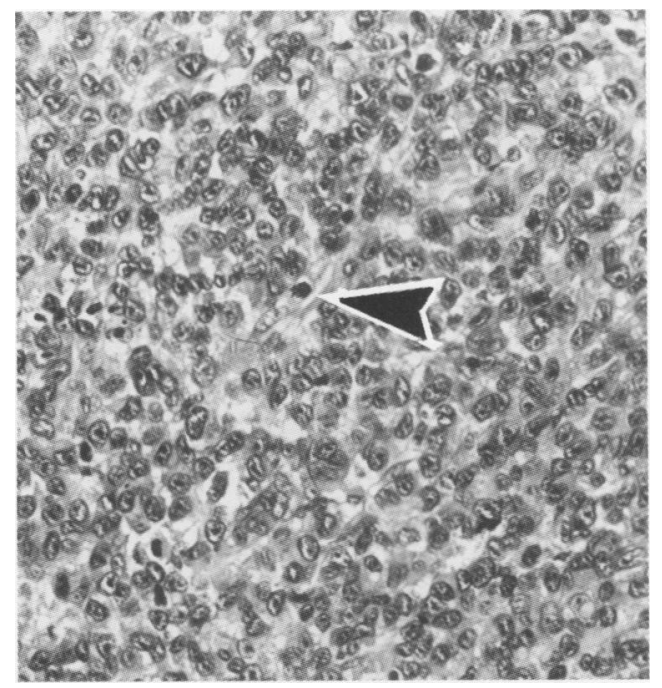

Figure 2 Melanoma showing mitotic figures (arrowheads), but no apoptotic figures. showing a wide range of values compared with superficial spreading and nodular malignant melanomas (fig 2). Expression of values as a ratio (apoptosis:mitosis) is shown in table 2 . The mean value of this ratio for basal cell carcinoma was 13.9 (median 10.0 ); for superficial spreading malignant melanoma the mean was 2.3 (median 1.3) and for nodular malignant melanoma the mean was 1.8 (median 1.3). The difference between the values for basal cell carcinoma and malignant melanoma is significant $(p<0.05)$. Neither the degree of lymphocytic inflammatory response, nor tumour thickness/level, nor ulceration had a significant effect on the apoptosis:mitosis ratio (data not shown).

Selected cases were studied using in situ end-labelling. Cell fragments similar to those morphologically resembling apoptotic cells stained with this technique, which does not stain mitotic cells (fig 3).

\section{Discussion}

Both malignant melanoma and basal cell carcinoma are tumours in which mitoses may be easily identified on light microscopy, but which display a marked disparity in growth rate. Kerr and Searle referred to this as the "paradoxically slow growth rate" of basal cell carcinoma and suggested that the high apoptotic rate, which they felt (without numerical quantification) to be approximately equal to the mitotic rate, might account for this. ${ }^{7}$

Our findings demonstrate that apoptotic cells outnumber mitotic cells in basal cell carcinoma, with considerable variation in the absolute number of apoptotic cells and a correspondingly wide range of apoptosis:mitosis ratios. By contrast, the melanomas had a similar number of mitoses to basal cell carcinoma, but a much smaller number of apoptotic cells and less of a ratio spread. As a simple index of cell turnover, there is a significant difference between the indolent basal cell carcinoma and more aggressive tumours. Whether there is a significant difference between superficial spreading and nodular malignant melanomas and whether the apoptosis:mitosis ratio is of prognostic significance will require assessment of a larger number of cases and correlation with clinical behaviour.

Assessment of mitotic figures has long been used as a prognostic index in certain soft tissue tumours, especially leiomyosarcoma. ${ }^{8}$ 


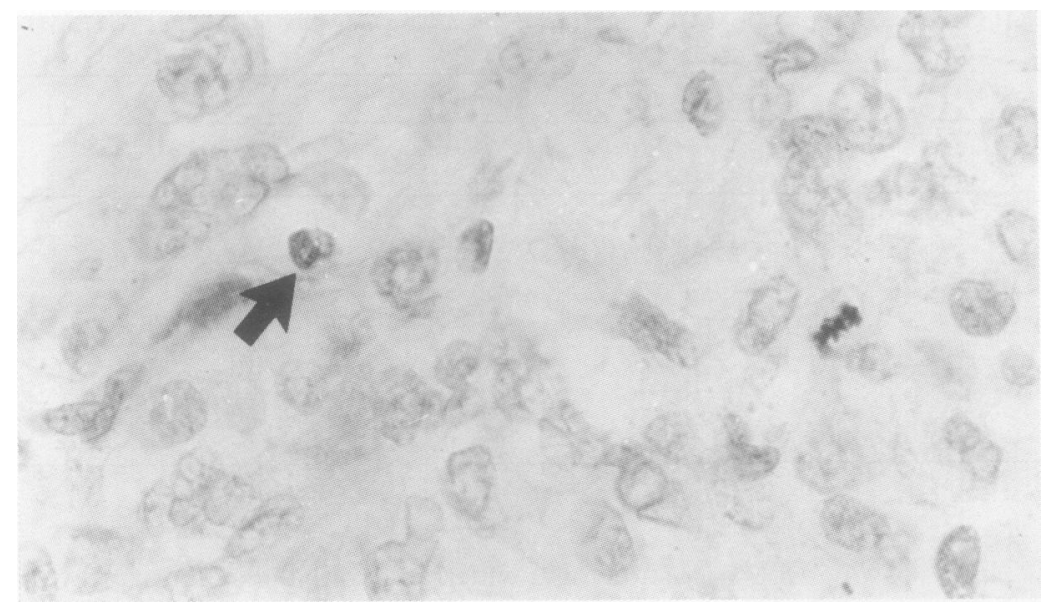

Figure 3 In situ end-labelling showing positive staining in an apoptotic cell (arrow) and no staining in an adjacent mitotic figure.

Traditionally, mitoses have been counted per high power field (hpf), which is inherently inaccurate being subject to variables such as size difference of microscope fields. ${ }^{9}$ Assessment per unit area or as a ratio of cells counted is more accurate and reproducible. As an index of cell proliferation, mitotic figure counting is perhaps the easiest first line assessment. However, it is only a crude reflection of growth fraction as different tumours may have a delayed cell cycle time giving apparently more mitoses at any one time. Despite this, mitotic rate alone is of prognostic value in a certain subset of melanomas. ${ }^{10}$ Coincident assessment of the number of apoptotic cells and the formulation of the apoptosis:mitosis ratio provides a figure which reflects tumour dynamics at the light microscopy level and may provide a numerical index of biological behaviour.

Although these cells demonstrate the morphological features of apoptotic cells on light microscopy and display breaks in internucleosomal double stranded DNA with in situ end-labelling, they may not all be the product of programmed cell death. ${ }^{4}$ This, however, does not invalidate the difference noted between the two tumour types studied here. As with mitotic figure estimation, counting of apoptotic bodies is subject to variables such as rate of clearance and the indeterminate number of nuclear or cytoplasmic fragments derived from individual cells. As such, assessment of mitotic and apoptotic indices can only be comparative, although proliferating cell nuclear antigen (PCNA) or Ki67 staining should verify any correlation between mitotic count and growth fraction.

It appears from the data that lymphocytic infiltration (which theoretically might be associated with a high apoptotic rate) has little effect on the apoptosis:mitosis ratio. The data also demonstrate that lymphocytes infiltrating tumours were not mistaken for apoptotic cells to any significant extent. Similarly, although ulceration of malignant melanoma is an independent prognostic variable, ${ }^{11}$ no correlation with apoptotic cells was found. Assessment of superficial areas of ulcerated tumours was performed away from areas of necrotic debris to avoid a falsely high apoptotic count. A slight trend towards a higher number of apoptotic cells and lower number of mitoses was seen in the superficial compared with the deep portion of the nodular malignant melanomas, but the small number of cases precludes statistical assessment (data not shown). Many superficial spreading malignant melanomas were too thin for superficial and deep areas to be demarcated. No difference was seen between superficial and deep areas in basal cell carcinomas.

In conclusion, this preliminary study identifies a significant difference in apoptotic:mitotic ratios between two tumour types, a difference which reflects their clinical behaviour. The apoptotic index correlates significantly with prognosis in non-Hodgkin's lymphomas. ${ }^{12}$ Although basal cell carcinoma may show a significant variation in growth rate, ${ }^{13}$ the principle application of a figure such as the apoptosis:mitosis ratio would be in malignant melanoma, where in certain cases, use of Clark's level or Breslow thickness alone may be misleading, ${ }^{14}$ and where assessment of other variables such as inflammatory response, regression or cell type has produced varying results. ${ }^{15-18}$

The authors would like to thank J Walker for assistance with photography.

1 Cotran RS, Kumar V, Robbins SL. Neoplasia. In: Cotran RS, Kumar V, Robbins SL, eds. Robbins pathologic basis of disease. 4th edn. Philadelphia: WB Saunders, 1989: 239-306.

2 Kerr JFR, Wyllie AH, Currie AR. Apoptosis: a basic biological phenomenon with wide-ranging implications in tissue kinetics. Br f Cancer 1972;26:239-57.

3 Gaverieli Y, Sherman Y, Ben-Sasson SA. Identification of programmed cell death in situ via specific labelling of nuclear DNA fragmentation. $\mathcal{F}$ Cell Biol 1992;119:493501.

4 Ansari B, Coates PJ, Greenstein BD, Hall PA. In situ endlabelling detects DNA strand breaks in apoptosis and other physiological and pathological states. $\mathscr{f}$ Pathol 1993; other physio $1-8$.

5 Breslow A. Thickness, cross-sectional areas and depth of invasion in the prognosis of cutaneous melanoma. Ann
intomal

6 Clark WH, From L, Bernardino EA, Mihm MC. The histogenesis and biologic behaviour of primary human malignant melanomas of the skin. Cancer Res 1969;29: 705-26.

7 Kerr JFR, Searle J. A suggested explanation for the paradoxically slow growth rate of basal-cell carcinomas that contain numerous mitotic figures. 7 Pathol 1972;107:41-4.

8 Enzinger FM, Weiss SW. Chapter 1. In: Soft tissue tumours. 2nd edn. St Louis: CV Mosby Co., 1988:1-19.

9 Ellis PSJ, Whitehead R. Mitosis counting-a need for reappraisal. Hum Pathol 1981;12:3-4.

10 Schmoeckel C, Braun-Falco O. Prognostic index in malignant melanoma. Arch Dermatol 1978;114:871-3.

11 Rosai J. Skin: Tumours and tumour-like conditions. In: Rosai J, ed. Ackerman's surgical pathology. 7th edn. St Louis: CV Mosby Co., 1989:88-172.

12 Leoncini L, Del Vecchio MT, Megha T, Barbini P, Galieni $\mathrm{P}$, Pileri S, et al. Correlations between apoptotic and proliferative indices in malignant non-Hodgkin's lymphomas. Am ₹ Pathol 1993;142:755-63.

13 Jacobs GH, Rippey JJ, Altini M. Prediction of aggressive behaviour in BCC. Cancer 1982;49:533-7.

14 Green MS, Ackerman AB. Thickness is not an accurate gauge of prognosis of primary cutaneous melanoma. Am $\Im$ Dermatopathol 1993;15:461-73.

15 Van der Esch EP, Cascinelli N, Preda F, Morabito A, Bufalino R. Stage 1 melanoma of the skin: Evaluation of prognosis according to histological characteristics. Cancer prognosis accordin

16 Clark WH, Elder DE, Guerry D, Braitman LE, Trock BJ, Schultz D, et al. Model predicting survival in stage 1 Schultz D, et al. Model predicting survival in stage 1
melanoma based on tumour progression. $\mathcal{f}$ Natl Cancer melanoma based on tum

17 Gromet MA, Epstein WL, Blois MS. The regressing thin malignant melanoma. A distinctive lesion with metastatic potential. Cancer 1978;42:2282-92.

18 McGovern VJ, Shaw HM, Milton GW. Prognosis in patients with thin malignant melanoma: influence of regression. Histopathology 1983;7:673-80. 